\title{
Nutrigenomics approach elucidates health-promoting effects of high vegetable intake in lean and obese men
}

\author{
W. J. Pasman • M. J. van Erk • W. A. A. Klöpping • \\ L. Pellis $\cdot$ S. Wopereis $\cdot$ S. Bijlsma $\cdot$ \\ H. F. J. Hendriks • A. F. M. Kardinaal
}

Received: 11 July 2012/Accepted: 14 March 2013/Published online: 18 April 2013

(C) The Author(s) 2013. This article is published with open access at Springerlink.com

\begin{abstract}
We aimed to explore whether vegetable consumption according to guidelines has beneficial health effects determined with classical biomarkers and nutrigenomics technologies. Fifteen lean (age $36 \pm 7$ years; BMI $23.4 \pm 1.7 \mathrm{~kg} \mathrm{~m}^{-2}$ ) and 17 obese (age $40 \pm 6$ years; BMI $30.3 \pm 2.4 \mathrm{~kg} \mathrm{~m}^{-2}$ ) men consumed 50 - or 200 -g vegetables for 4 weeks in a randomized, crossover trial. Afterward, all subjects underwent 4 weeks of energy restriction (60\% of normal energy intake). Despite the limited weight loss of $1.7 \pm 2.4 \mathrm{~kg}$ for the lean and $2.1 \pm 1.9 \mathrm{~kg}$ for the obese due to energy restriction, beneficial health effects were found, including lower total cholesterol, LDL cholesterol and $\mathrm{HbA} 1 \mathrm{c}$ concentrations. The high vegetable intake resulted in increased levels of plasma amino acid metabolites, decreased levels of 9-HODE and prostaglandin D3 and decreased levels of ASAT and ALP compared to low vegetable intake. Adipose tissue gene expression changes in response to vegetable intake were identified, and sets of selected genes were submitted to network analysis. The network of inflammation genes illustrated a central role for NFkB in (adipose tissue) modulation of inflammation by increased vegetable intake, in lean as well as obese subjects. In obese subjects, high vegetable intake also resulted in changes related to energy metabolism,
\end{abstract}

W. J. Pasman and M. J. van Erk contributed equally to this work.

Electronic supplementary material The online version of this article (doi:10.1007/s12263-013-0343-9) contains supplementary material, which is available to authorized users.

W. J. Pasman $(\bowtie) \cdot$ M. J. van Erk · W. A. A. Klöpping ·

L. Pellis · S. Wopereis - S. Bijlsma - H. F. J. Hendriks ·

A. F. M. Kardinaal

TNO, P.O. Box 360, 3700 AJ Zeist, The Netherlands

e-mail: wilrike.pasman@tno.nl adhesion and inflammation. By inclusion of sensitive omics technologies and comparing the changes induced by high vegetable intake with changes induced by energy restriction, it has been shown that part of vegetables' health benefits are mediated by changes in energy metabolism, inflammatory processes and oxidative stress.

Keywords Health · Inflammation · Obesity · Vegetables · Adipose tissue

\section{Introduction}

Consumption of vegetables is generally considered to be associated with several positive effects on health. It has been shown that low consumption of fruit and vegetables is related to more cardiovascular disease and cancer (KrebsSmith and Kantor 2001; Lock et al. 2005; Martinez-González et al. 2011; Mosby et al. 2012). Vegetables are a heterogeneous group of our diet with a low energy density and rich in bio-active compounds, such as vitamins, minerals, dietary fibers and phytochemicals like flavonoids and carotenoids (Tomás-Barberán and Robins 1997; Yao et al. 2004; Martinez-González et al. 2011; Mosby et al. 2012).

The recommended intake of vegetables by the Dutch Health Council is 150-200 g daily (Health Council of the Netherlands 2006). However, it has been reported that only $2 \%$ of the Dutch population meets the recommended daily intake of $150 \mathrm{~g}$ of vegetables (Health Council of the Netherlands 2006).

Conflicting results of vegetables have been found in epidemiological studies. Studies with large cohorts of subjects, often report reduced risks for certain diseases when vegetable consumption was increased. The World Cancer Research Fund reported in 2007 that diets 
containing substantial and varied amounts of vegetable and fruit intake (at least $400 \mathrm{~g} /$ day) will prevent $20 \%$ or more of all cancer cases (WCRF 2007). Also, cardiovascular disease risks are lower in subjects consuming more fruit and vegetables. In a meta-analysis of $\mathrm{Hu}$, it was found that consumption of green leafy vegetables had protective effects for coronary heart disease ( $\mathrm{Hu}$ 2003). Cruciferous vegetables and vitamin $\mathrm{C}$ rich citrus fruit and juices were found to protect against stroke ( $\mathrm{Hu}$ 2003). Also, the development of diabetes mellitus may be reduced with vegetable consumption (Bazzano et al. 2008; Villegas et al. 2008). Several specific compounds present in vegetables have been studied for their potential beneficial effects: antioxidants (especially polyphenols, lycopene and vitamin C) as free radical trapper; dietary fiber for its effect on gastro-intestinal functioning and related satiety; and glucosinolates present in the Brassicaceae vegetables family (cabbage; Brussels sprouts; cauliflower; broccoli), for their chemopreventive effect against cancer (Hayes et al. 2008). Based on epidemiological data, most national guidelines prescribe consumption of at least $200 \mathrm{~g}$ of vegetables and two pieces of fruit daily. The European Prospective Investigation into Cancer and Nutrition (the EPIC study) reported, however, no protective effect of total or specific vegetables intake against different types of cancer, like gastric cancer or urothelial cell carcinoma (Gonzalez et al. 2012; Ros et al. 2012).

Therefore, the inverse relationship of vegetable intake and disease risk is complex, also in relation to obesity. Vegetable consumption correlates with a lower risk of obesity (Martin et al. 2011; Myint et al. 2011), while increased body weight is related to increased risk of cancer (Wolin et al. 2010; La Vecchia et al. 2011), coronary (the Emerging Risk Factors Collaboration, 2011; Yusuf et al. 2005) and metabolic diseases (Boden 2008; Abdullah et al. 2010). Weight loss of 5-10\% of the initial body weight has been shown to improve risk profiles of diseases related to obesity (Wing et al. 1992; Tuomilehto et al. 2001). Also, weight loss due to caloric restriction will lead to changes in adipose tissue (Márquez-Quiñones et al. 2010; Bouchard et al. 2010).

Measuring the effects of a nutritional intervention such as increased vegetable intake is difficult, as the effects are likely to be subtle and variable across subjects. We and others have demonstrated that integration of omics technologies in nutrition research can yield more insights into effects of nutrition on health-related physiological processes (van Erk et al. 2008; Radonjic et al. 2009; Bakker et al. 2010).

The mechanisms of action for the vegetable intervention and the energy restriction on health may differ. High vegetable intake has been suggested to be mainly antiinflammatory due to its high antioxidant content (Calder et al. 2011). It is also possible that certain phenolic compounds of fruits and vegetables may also have some caloric restriction mimetic effects if they activate sirtuin deacetylases (Chen et al. 2008). Energy restriction will limit the effects of energy-driven processes like oxidative phosphorylation, mitochondrion activity, generation of precursor metabolites and energy (Calder et al. 2011).

In the present study, the effect of high vegetable consumption was investigated in a crossover trial by comparing this to low vegetable consumption in both lean and obese subjects. An energy-restricted dietary intervention was conducted in a parallel design after the crossover part, to examine whether part of the effects of vegetables may be attributed to similar mechanisms.

We performed a large-scale assessment of changes in a range of blood parameters using sensitive (omics) techniques. Analyses included the profiling of cytokines, amino acids and oxylipins to monitor the effect of the vegetable intervention on processes related to inflammation, oxidative stress, beta-oxidation and protein and amino acid metabolism. Furthermore, we assessed effects on adipose tissue by transcriptome analysis of adipose tissue biopsies. Interpretation of effects of high vegetable intake in light of effects induced by energy restriction gives additional insight into health-promoting effects of vegetables.

\section{Methods}

\section{Study design}

The study was a combination of a crossover trial for the vegetable intervention and a parallel setup for the third period. This was an energy-restricted diet intervention for all subjects.

Each intervention period lasted 4 weeks. With the high vegetable treatment, subjects consumed $200 \mathrm{~g}$ of vegetables daily, and with the low vegetable treatment, subjects consumed $50 \mathrm{~g}$ of vegetables daily. Subjects were free to consume their vegetables with lunch and/or with dinner. The vegetables were provided weekly by TNO; about ten different, most popular vegetables could be chosen; fresh vegetables for the first and second day of the week (tomatoes; beet; onions; cauliflower) and canned vegetables for the rest of the week [peas; carrots; French beans; broad beans; corn (mixture)]. Each type of vegetable could be chosen only once a week to guarantee a variation in the diet. Intake of fruit was limited to one piece a day to prevent confounding effects. Further food intake and lifestyle were maintained as usual.

The amount of food consumed during the energyrestricted diet intervention was based on the food intake diaries during the crossover interventions. All subjects 
were instructed to consume about $60 \%$ of their normal energy intake. A dietitian advised the subjects and monitored compliance.

The energy-restricted intervention was added as a positive control for vegetable treatment because of its known beneficial effects on health. Due to the expected weight loss in the energy-restricted period, no complete crossover design was applied in the study, because the effect of weight loss is expected to effect the next treatment.

The study was conducted at TNO (Zeist, the Netherlands). The study was approved by an independent centralized ethics committee (METOPP, Tilburg, the Netherlands) and is registered at Clinicaltrials.gov, number NCT 00959790.

After inclusion, subjects were randomly allocated to entry number and study treatment (vegetable dose order), in such a way that age and BMI were equally divided among treatment groups.

The study was designed as an open study, so subjects and investigators were aware of the dosage of vegetables consumed. The energy intake was different between the two vegetable treatments: in the $200-\mathrm{g}$ vegetable intervention, about 30-70 kcal was consumed with vegetable consumption, whereas this was $15-35 \mathrm{kcal}$ for vegetables in the 50-g vegetable intervention. This difference in energy intake was part of the intervention (the difference in energy intake is about $15-55 \mathrm{kcal} / \mathrm{day} ; 0.5-1.0 \%$ of the habitual daily energy intake (about 3,000 kcal for males/ day)). No energy compensation occured as could be concluded from the maintenance of body weights.

The difference of 150-g vegetable consumption affected the intake of vitamins and minerals; vitamin $\mathrm{C}$ (26 mg), vitamin B (total about $0.4 \mathrm{mg}$ ), lycopene $(153 \mu \mathrm{g})$, retinol equivalents (360 RE), lutein $(1,473 \mu \mathrm{g})$, sodium (71 mg), potassium (345 mg), calcium (65 mg), phosphorus (69 mg), magnesium (23 mg) and iron (69 mg) differed mostly between the two treatment dosages. The subjects were instructed to maintain their habitual body weight, food pattern and physical activity pattern in the first two intervention periods and to consume only the vegetables provided by TNO. To monitor food intake and compliance, subjects wrote down their food intake for 3 days in the second and fourth week of each treatment. Daily compliance of vegetable consumption was registered as well. On the day before each test day, all subjects consumed French beans as a standardized meal to reduce variation in the study samples.

\section{Subjects}

We selectively recruited apparently healthy, lean and overweight/obese, non-smoking male subjects. Sixty-three subjects came to TNO for an oral information session. Forty-eight subjects signed an informed consent. Thirtynine subjects were eligible, and 34 subjects were included. Two subjects dropped out during the study for non-studyrelated reasons; therefore, the study was completed with 32 subjects. Fifteen subjects were lean (BMI $23.4 \pm$ $1.7 \mathrm{~kg} \mathrm{~m}^{-2}$ ), and seventeen subjects were overweight/ obese (BMI $30.3 \pm 2.4 \mathrm{~kg} \mathrm{~m}^{-2}$ ). Subjects were aged between 18 and 45 years, exercised less than $2.5 \mathrm{~h}$ a week and were used and liked to eat vegetables. Subjects received financial compensation for their participation.

\section{Experimental protocol}

At the end of each 4-week intervention period, a test day was conducted (day 29, 57 and 85).

On each test day, a fasted blood sample was obtained. Physical variables like body weight, waist and hip circumferences and blood pressure were measured.

A standard breakfast was provided after blood sampling. A maximal exercise test was performed after breakfast consumption. The results of the exercise tests will be presented elsewhere.

Blood and urine clinical chemistry analyses

Blood samples were obtained from the antecubital vein of the forearm and collected in tubes containing clot activator for serum and in tubes containing EDTA for plasma (Vacutainer Systems, Becton-Dickinson, Plymouth, U.K.). Blood was centrifuged for $15 \mathrm{~min}$ at $2,000 \mathrm{~g}$ and $4{ }^{\circ} \mathrm{C}$ within $30 \mathrm{~min}$ after collection. Plasma and serum samples were stored at $<-70{ }^{\circ} \mathrm{C}$ until analysis.

Serum clinical chemistry tests included the measurement of glucose, triacylglycerol (TG), free fatty acids (FFA), glycerol, insulin, HbA1c, total cholesterol and HDL-cholesterol, $\gamma$-GT, ALAT, ASAT, ALP, hamatology, total bilirubin, urea, uric acid, creatinine, lactate, creatine kinase and myoglobin and were performed using Olympus analytical equipment and reagents (Olympus AU400 clinical chemistry analyzer; Olympus-Diagnostica Europe, Hamburg, Germany).

Plasma samples of 10 lean and 10 obese subjects were used for multiplex analysis of 6 inflammatory proteins: GM-CSF, IFNgamma, IL-1beta, IL-6, IL-8 and TNF-alpha (Mesoscale Discovery). Plasma levels of IFNgamma and IL-1beta were too low and could not be detected.

Plasma profiling of oxylipins and amino acids

To monitor the effect of the vegetable intervention on processes related to inflammation, oxidative stress, betaoxidation and protein and amino acid metabolism, blood 
samples were collected for liquid chromatography-mass spectrometry (LC-MS) analysis of oxylipins and amino acids after an overnight fast at the end of the 4-week low and high vegetable interventions. For oxylipin analysis, blood was collected in tubes containing EDTA. These blood samples were directly supplemented with an inhibitor cocktail containing paraoxon, butylated hydroxytoluene (BHT), indomethacin and phenyl methyl sulfonylfluoride (PMSF) with the following proportions 1 BHT: 1 Indomethacin: 10 Paraoxon: 1 PMSF to prevent oxylipin oxidation and breakdown. For amino acid analysis, blood was collected in tubes containing Li-heparin as anti-coagulant. Blood was put on ice till centrifugation. All samples were centrifuged within $30 \mathrm{~min}$ after collection. Blood was centrifuged for $15 \mathrm{~min}$ at $2,000 \mathrm{~g}$ and $4{ }^{\circ} \mathrm{C}$. Plasma and serum samples were stored at $<-70{ }^{\circ} \mathrm{C}$ until analysis.

The LC-MS/MS method used for the measurement of plasma oxylipins and the LC-MS method used for the measurement of a broad range of plasma amino acids and derivatives were identical to the methods reported by, respectively, Balvers et al. (2012) and Rosenling et al. (2009). The samples were analyzed in randomized order. For amino acids, data for each subject were corrected for the recovery of the internal standard for injection. The performance of the applied metabolic profiling platforms was assessed through the frequent analysis of the quality control sample. Finally, the oxylipin data set contained 21 metabolites and the amino acid data set consisted of 51 metabolites (see Supplementary File 1).

\section{Fat biopsy}

After 3 weeks of treatment intervention, at day 22, 50 and 78 , an abdominal, subcutaneous fat sample was obtained after an overnight fast from all subjects. Human abdominal fat biopsies were taken according to Kolaczynski et al. (1994). Briefly, subcutaneous adipose tissue was obtained by needle aspiration under local anesthesia using two syringes of $50 \mathrm{~mL} 8.4 \% \mathrm{NaHCO} 3,0.05 \%$ lidocaine and $1.0 \mathrm{mg} / \mathrm{ml}$ epinephrine. The two syringes used for fat collection contained in total about $10 \mathrm{~mL}$ of adipose tissue. The adipose tissue was divided over cryovials, immediately frozen in liquid nitrogen and stored at $-80{ }^{\circ} \mathrm{C}$ for RNA isolation (van Erk et al. 2008).

\section{Transcriptomics}

Total RNA was extracted from adipose tissue samples from 10 lean and 10 obese subjects (a subset of subjects in both groups) using RNAzol (Campro Scientific, Veenendaal, the Netherlands) and glass beads according to the manufacturer's instructions. RNA was subjected to a cleanup step using NucleoSpin columns (Macherey-Nagel, Germany).
Quality control, RNA labeling, hybridization and data extraction were performed at ServiceXS (Leiden, the Netherlands). RNA concentration was measured using a Nanodrop ND-1000 spectrophotometer (Nanodrop Technologies, Wilmington, DE, USA). The RNA quality and integrity was determined using Lab-on-Chip analysis on an Agilent 2100 Bioanalyzer (Agilent Technologies, Inc., Santa Clara, CA, USA). The Ambion Illumina total prep 96 kit was used to create biotinylated cRNA from the RNA samples. For the hybridization, wash and stain steps and scanning of the Illumina BeadChips the Illumina protocol: "Whole-Genome Gene Expression Direct Hybridization Assay" was followed strictly. The amount of biotinylated cRNA hybridized onto the HumanHT-12 v.3 Expression BeadChip was 750 ng. In total, 60 RNA samples from adipose tissue were of sufficient quality and subjected to array analysis.

Due to scanning problems for one sample, data of 19 subjects were included in further analysis.

Data were extracted using GenomeStudio. Quality control and normalization (quantile) of microarray data was performed in Genespring GX11.0. Non-expressed genes were removed by filtering on detection value ( $p$ value $\geq 0.99$ in at least one sample). This resulted in gene expression values for 21,525 genes with unique identifiers.

The microarray data will be made available in the GEO database (http://www.ncbi.nlm.nih.gov/geo/).

\section{Statistics}

The number of subjects participating in the present study was based on the main health biomarker "oxidative stress." This parameter was tested with a maximal exercise performance on a cycle ergometer, and therefore, the number of subjects reported in the review of Fisher-Wellman and Bloomer (2009) was used for the determination of group size in the present study.

The vegetable interventions (health effect) were tested according to the crossover design and the energy-restricted period according to the parallel design. For the crossover design, all variables were compared between treatments and weight class with a mixed model that included treatment, weight class and the interaction between weight class and treatment as fixed factors and period and subject as random factors. If the analysis indicated an interaction between weight class (lean and obese) and treatment $(p<0.05)$, comparisons between means of the parameters were performed using a 2-sided Student $t$ test. A mixed model on the difference between last measurement in the second intervention period (last measurement in crossover design) and the measurement after the third intervention (energy restriction) was used to investigate the effect of the caloric restriction. Although the statistics is performed on the changes resulting from energy restriction (comparison of 
values after energy restriction period to values before energy restriction period), to control for prior vegetable dose (high or low), in the tables, the absolute values are presented.

If necessary, data were log-transformed and statistical outliers (defined as an observation for which the absolute residual was three times higher than the square root of the model error) were removed. In all statistical tests performed, the null hypothesis (no effect) was rejected at the 0.05 level of probability.

Expression data of the transcriptomics were log-transformed (base 2). To reveal the effect of high vegetables, a two-way ANOVA was applied with the following factors: group (lean/obese), treatment (high vegetables/low vegetables) and interaction. If the ANOVA assumptions were not met, data were rank-transformed and the ANOVA model was applied on rank-transformed data. In all statistical tests performed, the null hypothesis (no effect) was rejected at the 0.05 level of probability. In addition to a threshold on $p$ value, a threshold was applied to fold change induced by intervention. Genes were used for biological interpretation if the $p$ value threshold was passed and if the intervention resulted in more than $25 \%$ expression difference in same direction in at least $60 \%$ of the subjects (all up or all down).

Pearson correlation coefficients were calculated between gene expression changes (2log ratio for after vs. before energy restriction) and body weight change. Genes with correlation coefficient above 0.7 or below -0.7 were selected and submitted to enrichment analysis in DAVID (Huang et al. 2009). When correlation was contributable to one outlier value, these were not taken into account for interpretation. Statistical analyses were performed using the SAS statistical software package (SAS version 8.2, SAS Institute, Cary, NC, USA).

\section{Biological interpretation}

Gene enrichment analysis was performed using DAVID Functional enrichment tools (http://david.abcc.ncifcrf.gov/) (Huang et al. 2009), selecting enriched gene groups $(p<0.05)$ with 5 or more differentially expressed genes. Network analysis of genes, proteins and metabolites was performed in MetaCore version 6.7 (GeneGo Inc., St. Joseph, MI, USA), using the shortest path algorithm (max 2 steps). Prostaglandin D3 and Methionine sulfoxide were not present in the MetaCore database and were therefore excluded from network analysis.

\section{Results}

This study aimed to investigate the effect of high vegetable consumption in lean and obese subjects compared to low
Table 1 Baseline characteristics and fasting blood data of the lean $(n=15)$ and obese $(n=17)$ men who completed the study (mean $\pm \mathrm{SD}$ is presented)

\begin{tabular}{lccl}
\hline Parameter & $\begin{array}{l}\text { Lean } \\
(n=15)\end{array}$ & $\begin{array}{l}\text { Obese } \\
(n=17)\end{array}$ & $p$ value \\
\hline Age (years) & $36 \pm 7$ & $40 \pm 6$ & N.S. \\
Body weight $(\mathrm{kg})$ & $82.9 \pm 9.2$ & $101.4 \pm 11.4$ & $<0.001$ \\
BMI $\left(\mathrm{kg} \mathrm{m}^{-2}\right)$ & $23.4 \pm 1.7$ & $30.3 \pm 2.4$ & $<0.001$ \\
Waist circumference (cm) & $88.9 \pm 4.8$ & $105.6 \pm 6.6$ & $<0.001$ \\
Waist-hip ratio & $0.89 \pm 0.04$ & $0.97 \pm 0.04$ & $<0.001$ \\
Systolic blood pressure & $120 \pm 13$ & $127 \pm 12$ & N.S. \\
$\quad$ (mm Hg) & $79 \pm 9$ & $83 \pm 11$ & N.S. \\
Diastolic blood pressure & & & \\
$\quad$ (mm Hg) & $5.5 \pm 0.4$ & $5.6 \pm 0.4$ & N.S. \\
Glucose (mmol/L) & $6.2 \pm 2.4$ & $12.9 \pm 6.5$ & $<0.05$ \\
Insulin (mmol/L) & $5.1 \pm 0.2$ & $5.0 \pm 0.2$ & N.S. \\
HbA1c (\%) & $4.9 \pm 0.6$ & $5.7 \pm 0.7$ & $<0.05$ \\
Total cholesterol (mmol/L) & $1.3 \pm 0.3$ & $1.2 \pm 0.2$ & + \\
HDL-cholesterol (mmol/L) & $3.0 \pm 0.4$ & $3.6 \pm 0.5$ & $<0.05$ \\
\hline LDL-cholesterol (mmol/L) & $3.0 \pm$
\end{tabular}

+ Represents a tendency $(p<0.1) ;$ N.S. means not significant

vegetable consumption. The baseline characteristics and fasting blood data of the subjects are shown in Table 1. Not only body weight, BMI, waist circumference and waist-hip ratio were different between lean and obese group, but also levels of insulin, total cholesterol and LDL cholesterol. All these parameters were significantly higher in the obese compared to the lean group.

\section{Compliance in the study}

Compliance of vegetable consumption was evaluated at the end of the vegetable treatments, by registration of the daily intake of the vegetables. If study substances were not consumed or the amount was not equal to the required 50 or $200 \mathrm{~g}$, this was registered as a protocol deviation. In the two times 4-week treatment period, the 32 subjects were supposed to consume 1,792 portions of vegetables in total. Twenty vegetable consumption protocol deviations (more or less vegetable intake, evenly divided (some forgot, some consumed more)) were registered and therefore compliance for vegetable intake was $98.9 \%$. When the 16 fruit intake deviations were taken into account as well (mainly consumption of two pieces of fruit in stead of one) (in total 36 fruit and vegetable consumption deviations were reported), compliance was still $98.0 \%$. Compliance to vegetable treatment was therefore qualified as good.

During the energy-restricted intervention, subjects were instructed to consume about 30-40 \% less energy daily (individual advices were given by the dietitian), which was 
calculated to result in $\sim 1 \mathrm{~kg}$ weight loss per week. The caloric restriction intervention resulted in weight loss in lean and obese subjects $(-1.7 \pm 2.4 \mathrm{~kg}$ in lean and $-2.1 \pm 1.9 \mathrm{~kg}$ in obese). The weight loss was significant over time $(p<0.0001)$, but not different between the lean and obese. This amount of weight loss was about $50 \%$ of the amount expected after 4 weeks of energy restriction; therefore, the compliance was also about $50 \%$. The compliance during the energy-restricted diet period was therefore qualified as moderate.

\section{Plasma markers}

The caloric restriction intervention was used as a positive control condition to evaluate the effects found with the vegetable interventions. Tables 2 and 3 indicate the plasma marker changes in response to the caloric restriction and the vegetable intervention, respectively. Overall, the changes were not different between lean and obese subjects; very few markers showed a significant different response in obese compared to lean subjects (significant interaction in ANOVA).

Blood levels of total cholesterol, LDL cholesterol, ratio of cholesterol/HDL, $\gamma$-GT, ASAT and HbA1c decreased significantly in response to the energy restriction diet in both lean and obese groups (Table 2).

Only fasting ASAT and ALP levels were lower after consumption of $200-\mathrm{g}$ vegetables compared to $50 \mathrm{-g}$ vegetables in both lean and obese subjects (Table 3). TNF- $\alpha$, an inflammation marker, showed an interaction between weight class and treatment: $\mathrm{TNF}-\alpha$ levels were significantly lower in lean men after $200 \mathrm{~g}$ of vegetable treatment compared to the $50 \mathrm{~g}$ of vegetable treatment.

The inventory of health-promoting effects of vegetables in lean and obese subjects included measurements of plasma metabolites related to amino acids and derivatives $(n=51)$ and oxylipins $(n=21)$ (see Supplementary File 1) and measurement of 4 inflammatory plasma proteins (IL-6, IL-8, TNF- $\alpha$ and GM-CSF). The plasma metabolites with a significant change related to vegetable intake are summarized in Table 4. Intake of $200 \mathrm{~g}$ compared to $50 \mathrm{-g}$ vegetables resulted in increased plasma levels of asparagine $(+6.8 \%)$, leucine $(+5.0 \%)$, methionine sulfoxide $(+15 \%)$ and threonine $(+5.9 \%)$. Levels of 9-HODE $(-21.4 \%)$ and prostaglandin D3 $(-16.7 \%)$ were significantly lower in response to the $200-\mathrm{g}$ vegetable intake compared to $50 \mathrm{-g}$ vegetable intake. Uniquely in obese subjects, levels of 15-HETE were lowered $(-31.7 \%)$. Vegetable intake did not result in significant changes in inflammatory plasma proteins IL-6, IL-8, TNF- $\alpha$ and GMCSF in this selected group of subjects and analysis.

\section{Effects of increased vegetable intake on adipose tissue}

We aimed to investigate the effect of increased vegetable intake on adipose tissue in lean and obese subjects by gene expression analysis. Overall, limited gene expression changes were observed due to high vegetable intake compared to low vegetable intake: 323 genes were affected in obese subjects and 532 genes in lean. The differentially expressed genes in lean subjects were enriched for genes involved in immune and inflammatory response. In lean

Table 2 Changes in blood parameters after the energy-restricted (ER) intervention (mean \pm SD is presented)

\begin{tabular}{|c|c|c|c|c|c|}
\hline \multirow[t]{2}{*}{ Treatment } & \multicolumn{2}{|c|}{ Lean $(n=15)$} & \multicolumn{2}{|c|}{ Obese $(n=17)$} & \multirow[t]{2}{*}{$p$ value } \\
\hline & Before ER & After ER & Before ER & After ER & \\
\hline Glucose (mmol/L) & $5.4 \pm 0.3$ & $5.5 \pm 0.3$ & $5.7 \pm 0.3$ & $5.7 \pm 0.4$ & N.S. \\
\hline Insulin (mU/L) & $5.9 \pm 3.3$ & $5.0 \pm 2.7$ & $12.7 \pm 6.1$ & $11.0 \pm 6.8$ & N.S. \\
\hline HbA1c $(\%)$ & $5.1 \pm 0.2$ & $5.0 \pm 0.2$ & $5.1 \pm 0.2$ & $5.0 \pm 0.1$ & $<0.05$ \\
\hline Total cholesterol (mmol/L) & $5.2 \pm 0.7$ & $4.7 \pm 0.7$ & $6.0 \pm 0.7$ & $5.4 \pm 0.5$ & $<0.05$ \\
\hline HDL-cholesterol (mmol/L) & $1.3 \pm 0.4$ & $1.3 \pm 0.3$ & $1.2 \pm 0.2$ & $1.1 \pm 0.2$ & N.S. \\
\hline LDL-cholesterol (mmol/L) & $3.3 \pm 0.6$ & $2.9 \pm 0.6$ & $3.9 \pm 0.6$ & $3.5 \pm 0.4$ & $<0.05$ \\
\hline Ratio cholesterol/HDL & $4.3 \pm 1.2$ & $3.8 \pm 0.9$ & $5.3 \pm 0.9$ & $4.9 \pm 0.9$ & $<0.05$ \\
\hline Triacylglycerol (mmol/L) & $1.4 \pm 0.7$ & $1.1 \pm 0.5$ & $2.2 \pm 1.2$ & $2.1 \pm 1.4$ & N.S. \\
\hline$\gamma$-GT (U/L) & $23.4 \pm 11.2$ & $18.2 \pm 8.0$ & $33.9 \pm 12.8$ & $27.5 \pm 12.5$ & $<0.05$ \\
\hline ALAT (U/L) & $12 \pm 4$ & $12 \pm 4$ & $19 \pm 11$ & $19 \pm 11$ & N.S. \\
\hline ASAT (U/L) & $21 \pm 4$ & $20 \pm 4$ & $26 \pm 8$ & $24 \pm 6$ & + \\
\hline ALP (U/L) & $64 \pm 12$ & $60 \pm 10$ & $67 \pm 18$ & $65 \pm 14$ & N.S. \\
\hline TNF- $\alpha(\mathrm{pg} / \mathrm{mL})^{\mathrm{a}}$ & $0.97 \pm 0.29$ & $0.88 \pm 0.18$ & $1.08 \pm 0.34$ & $1.11 \pm 0.39$ & N.S. \\
\hline
\end{tabular}

\# $p$ values for treatment effect in 2-way ANOVA, interaction effects (BMI-category $\times$ treatment) were not significant

$+p<0.1$ (tendency)

${ }^{\text {a }}$ Two lean subjects were excluded from the TNF- $\alpha$ dataset because they were outliers, $E R$ energy restriction 
Table 3 Changes in blood clinical chemistry parameters after the vegetable intervention (mean \pm SD is presented)

\begin{tabular}{|c|c|c|c|c|c|}
\hline \multirow[t]{2}{*}{ Treatment } & \multicolumn{2}{|c|}{ Lean $(n=15)$} & \multicolumn{2}{|c|}{ Obese $(n=17)$} & \multirow[t]{2}{*}{$p$ value } \\
\hline & $50-\mathrm{g}$ Veg & 200-g Veg & $50-\mathrm{g} \mathrm{Veg}$ & 200-g Veg & \\
\hline Glucose (mmol/L) & $5.4 \pm 0.3$ & $5.4 \pm 0.3$ & $5.7 \pm 0.4$ & $5.9 \pm 0.1$ & N.S. \\
\hline Insulin (mU/L) & $5.5 \pm 2.6$ & $5.9 \pm 3.2$ & $11.0 \pm 5.2$ & $13.4 \pm 6.7$ & N.S. \\
\hline $\mathrm{HbA1c}(\%)$ & $5.1 \pm 0.2$ & $5.1 \pm 0.2$ & $5.1 \pm 0.1$ & $5.1 \pm 0.2$ & N.S. \\
\hline Total cholesterol (mmol/L) & $5.1 \pm 0.7$ & $5.2 \pm 0.6$ & $6.0 \pm 0.8$ & $5.8 \pm 0.7$ & N.S. \\
\hline HDL-cholesterol (mmol/L) & $1.3 \pm 0.3$ & $1.3 \pm 0.3$ & $1.2 \pm 0.2$ & $1.1 \pm 0.2$ & N.S. \\
\hline LDL-cholesterol (mmol/L) & $3.2 \pm 0.6$ & $3.4 \pm 0.4$ & $3.9 \pm 0.6$ & $3.8 \pm 0.6$ & N.S. \\
\hline Ratio cholesterol/HDL & $4.2 \pm 1.2$ & $4.2 \pm 0.9$ & $5.3 \pm 0.9$ & $5.3 \pm 0.9$ & N.S. \\
\hline Triacylglycerol $(\mathrm{mmol} / \mathrm{L})$ & $1.3 \pm 0.7$ & $1.2 \pm 0.5$ & $2.2 \pm 1.2$ & $2.2 \pm 1.7$ & N.S. \\
\hline$\gamma$-GT (U/L) & $23.3 \pm 10.9$ & $22.4 \pm 10.8$ & $34.3 \pm 13.1$ & $32.9 \pm 11.6$ & N.S. \\
\hline ALAT (U/L) & $13 \pm 4$ & $11 \pm 4$ & $21 \pm 15$ & $21 \pm 10$ & N.S. \\
\hline ASAT (U/L) & $21 \pm 4$ & $20 \pm 4$ & $26 \pm 8$ & $25 \pm 8$ & $<0.05$ \\
\hline ALP (U/L) & $63 \pm 11$ & $61 \pm 11$ & $67 \pm 18$ & $64 \pm 15$ & $<0.05$ \\
\hline $\mathrm{TNF}-\alpha(\mathrm{pg} / \mathrm{mL})^{\mathrm{a}}$ & $1.03 \pm 0.28$ & $0.84 \pm 0.17$ & $1.11 \pm 0.41$ & $1.09 \pm 0.36$ & $0.0067 *$ \\
\hline
\end{tabular}

\# $p$ values for treatment effect in 2-way ANOVA, interaction effects (BMI-category $\times$ treatment) were not significant

$* p$ value for vegetable effect in lean subjects (post hoc test); $p$ value for interaction (BMI-category $\times$ treatment) was 0.0491

${ }^{a}$ Two lean subjects were excluded from the TNF- $\alpha$ dataset because they were outliers; g, gram and Veg, vegetable

Table 4 Significant changes in blood metabolites after the vegetables intervention (mean \pm SD is presented)

\begin{tabular}{|c|c|c|c|c|c|}
\hline \multirow[t]{2}{*}{ Treatment } & \multicolumn{2}{|l|}{ Lean $(n=15)$} & \multicolumn{2}{|l|}{ Obese $(n=17)$} & \multirow[t]{2}{*}{$p$ value $^{\#}$} \\
\hline & 50-g Veg & 200-g Veg & 50-g Veg & 200-g Veg & \\
\hline $\begin{array}{l}\text { Asparagine } \\
\text { (Asn) }\end{array}$ & $0.30 \pm 0.06$ & $0.32 \pm 0.06$ & $0.28 \pm 0.05$ & $0.30 \pm 0.07$ & 0.0418 \\
\hline Leucine (Leu) & $1.61 \pm 0.13$ & $1.65 \pm 0.15$ & $1.83 \pm 0.33$ & $1.96 \pm 0.36$ & 0.0224 \\
\hline $\begin{array}{l}\text { Methionine } \\
\text { sulfoxide } 1\end{array}$ & $1.9 \times 10^{-3} \pm 8.8 \times 10^{-4}$ & $2.2 \times 10^{-3} \pm 2.9 \times 10^{-4}$ & $1.9 \times 10^{-3} \pm 3.7 \times 10^{-4}$ & $2.2 \times 10^{-3} \pm 5.7 \times 10^{-4}$ & 0.0308 \\
\hline $\begin{array}{l}\text { Methionine } \\
\text { sulfoxide } 2\end{array}$ & $2.7 \times 10^{-3} \pm 1.2 \times 10^{-3}$ & $2.9 \times 10^{-3} \pm 4.2 \times 10^{-4}$ & $2.6 \times 10^{-3} \pm 6.7 \times 10^{-4}$ & $3.1 \times 10^{-3} \pm 7.2 \times 10^{-4}$ & 0.0455 \\
\hline Threonine (Thr) & $2.32 \pm 0.25$ & $2.37 \pm 0.28$ & $2.26 \pm 0.39$ & $2.49 \pm 0.53$ & 0.0205 \\
\hline 9-HODE & $2.62 \pm 0.83$ & $2.20 \pm 1.30$ & $3.00 \pm 1.31$ & $2.21 \pm 0.46$ & 0.0187 \\
\hline PGD-3 & $0.024 \pm 0.024$ & $0.020 \pm 0.021$ & $0.017 \pm 0.016$ & $0.013 \pm 0.016$ & 0.0408 \\
\hline 15-HETE & $0.08 \pm 0.03$ & $0.10 \pm 0.05$ & $0.12 \pm 0.06$ & $0.08 \pm 0.04$ & $0.0263 *$ \\
\hline
\end{tabular}

$G$ gram; Veg vegetable

\# $p$ values for treatment effect in 2-way ANOVA, interaction effects (BMI-category $\times$ treatment) were not significant

$* p$ value for vegetable effect in obese subjects (post hoc test); $p$ value for interaction (BMI-category $\times$ treatment) was 0.006

subjects, high vegetable consumption resulted in reduced expression of adipose tissue genes IL- 8 and NFKB2 and increased expression of adipose tissue genes complement component 3 (C3) and NFKB inhibitor NFKBIB. The Table in Supplementary File 2 lists the 40 differentially expressed genes in lean subjects annotated to these processes. In obese subjects, no gene ontology biological processes were enriched in the set of 323 genes.

We investigated to what extent adipose tissue gene expression changes in response to caloric restriction were associated with weight loss. Weight loss in response to caloric restriction was similar to lean and obese subjects. However, very limited gene expression changes were associated with amount of weight loss when all subjects were taken together ( 6 genes with $r>10.71$, data not shown). Next, lean and obese subjects were analyzed separately, to check for correlations within these groups. In the group of obese subjects, 641 genes showed high correlation $(r>10.71)$ to body weight change compared to 303 genes in the group of lean subjects. Enrichment analysis showed that in obese subjects, body weight change due to caloric restriction intervention correlated with gene 
Fig. 1 Enrichment analysis of 641 genes with high correlation to body weight change in 10 obese subjects

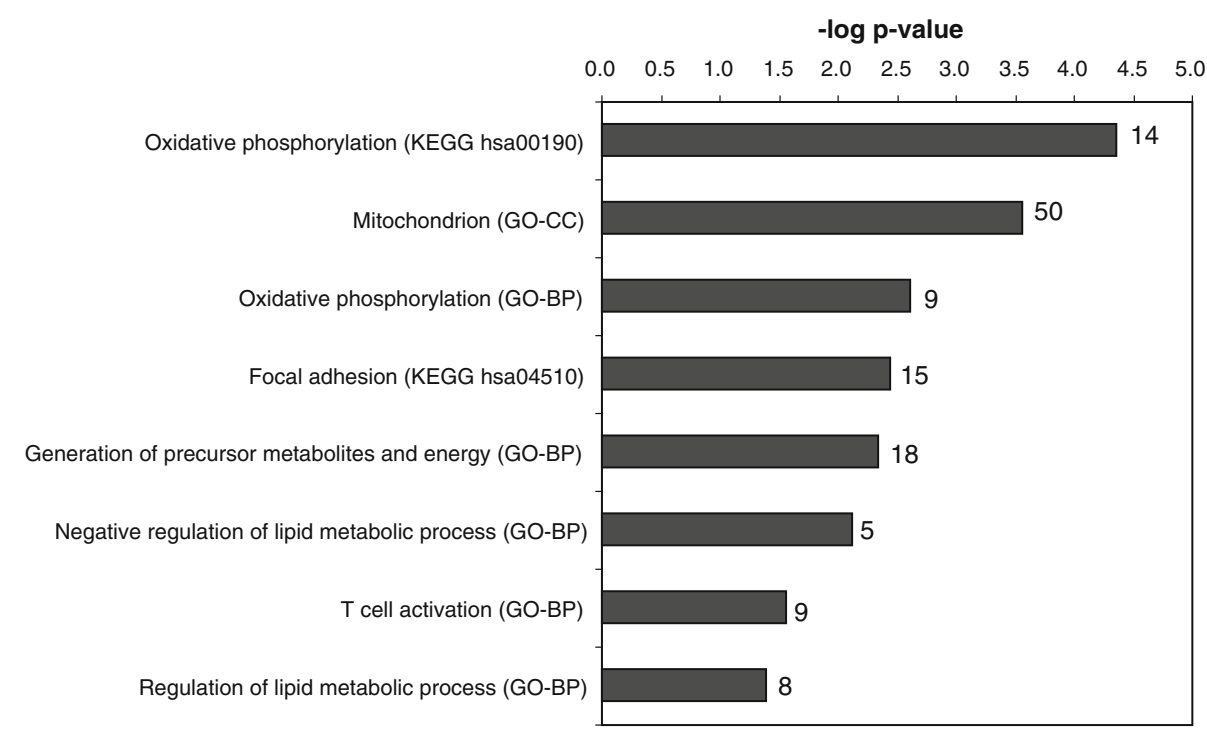

expression responses in processes of energy metabolism (oxidative phosphorylation, mitochondrion, generation of precursor metabolites and energy, regulation of lipid metabolism), focal adhesion and inflammation ( $\mathrm{T}$ cell activation) in adipose tissue (Fig. 1). In lean subjects, mainly gene expression changes related to inflammatory response processes correlated with body weight change. However, these were contributable to outlier values for 1 subject and therefore not taken into account further.

Although we were not able to detect enriched processes related to vegetable intake in obese subjects based on the set of 323 differentially expressed genes (see above), we now investigated whether in obese subjects, the increased vegetable consumption did affect expression of genes annotated to the processes that were associated with weight loss in obese subjects. Table 5 lists differentially expressed genes (consistent expression change, i.e. $>25 \%$ up or $>25 \%$ down in at least 6 subjects, combined with $p<0.05$ in ANOVA) in response to high vegetable intake compared to low vegetable intake involved in energy metabolism, adhesion and inflammation in obese subjects. This resulted in 16 genes for energy metabolism, 18 genes for cell adhesion and 19 genes for inflammation.

\section{Data integration}

We performed network analysis based on biological knowledge using MetaCore software to integrate the data, from plasma as well as adipose tissue.

In lean subjects, high vegetable intake resulted in differential expression of 40 genes annotated to immunerelated processes. The biological network in Fig. 2 shows direct interactions between 15 of these genes and plasma TNF-alpha, with transcription factor NFkB as a central regulator. Furthermore, network analysis showed that
9-HODE (measured in plasma) may be linked to this network through PPAR $\gamma$. Potential anti-inflammatory effects of high vegetable intake in lean subjects are supported by down-regulation of NF-kB and target genes like tissue factor and IL-8 in adipose tissue as well as down-regulation of TNF-alpha levels in plasma.

To illustrate possible biological links between observed effects of high vegetable intake on obese subjects, biological networks on the basis of inflammation, energy metabolism and adhesion genes from Table 4 together with the significantly changed plasma metabolites and classical markers were created. The network in Fig. 3 shows that the inflammatory gene expression changes due to vegetable intervention in adipose tissue may be regulated by $\mathrm{NFkB}$ and PPAR $\gamma$ and that 9-HODE and 15-HETE (measured in plasma) may be linked to this network through PPAR $\gamma$. All but two inflammatory genes listed in Supplementary File 2 are connected in the network. Furthermore, the network in Fig. 4 illustrates a biological link between 9-HODE and 15-HETE and specific energy metabolism genes, also through PPAR $\gamma$. In addition to $\operatorname{PPAR} \gamma$, many other transcription factors may be involved in the regulation of energy metabolism in obese subjects, for example, CREB1, STAT5A, ESR2, ESR1 and SP1. Through these regulators, the plasma markers ASAT (AATC) and ALP (ALPL) were also linked to this network.

Biological network analysis did not reveal a link between the expression changes of adhesion genes and the plasma biomarker changes (see Supplementary File 3).

\section{Discussion}

By integration of sensitive omics technologies with classic and modern metabolome biomarkers, we were able to show 
Table 5 Expression changes in obese subjects in response to high vegetable intake compared to low vegetable intake related to inflammation, energy metabolism and adhesion

\begin{tabular}{|c|c|c|c|c|c|}
\hline Definition & Symbol & Probe_Id & $\begin{array}{l}\text { Entrez } \\
\text { Gene ID }\end{array}$ & $\begin{array}{l}\text { Mean } \\
\text { 2log ratio }\end{array}$ & \\
\hline \multicolumn{6}{|l|}{ Energy metabolism } \\
\hline $\begin{array}{l}\text { Glutamate-ammonia ligase (glutamine synthetase) (GLUL), transcript variant } 3 \text {, } \\
\text { mRNA }\end{array}$ & GLUL & ILMN_1765208 & 2752 & 0.67 & $a$ \\
\hline $\begin{array}{l}\text { Runt-related transcription factor } 1 \text {; translocated to, } 1 \text { (cyclin D-related) } \\
\text { (RUNX1T1), transcript variant } 3 \text {, mRNA }\end{array}$ & RUNX1T1 & ILMN_1710522 & 862 & 0.65 & $\mathrm{a}$ \\
\hline $\begin{array}{l}\text { Peroxisome proliferator-activated receptor gamma, coactivator-related } 1 \\
\text { (PPRC1), mRNA }\end{array}$ & PPRC1 & ILMN_1796210 & 23082 & 0.65 & b \\
\hline $\begin{array}{l}\text { SLIT-ROBO Rho GTPase activating protein } 2 \text { (SRGAP2), transcript variant } 1 \text {, } \\
\text { mRNA }\end{array}$ & SRGAP2 & ILMN_1759549 & 23380 & 0.57 & $\mathrm{~b}$ \\
\hline $\begin{array}{l}\text { Pyruvate carboxylase (PC), nuclear gene encoding mitochondrial protein, } \\
\text { transcript variant } 3 \text {, mRNA }\end{array}$ & $\mathrm{PC}$ & ILMN_1736689 & 5091 & 0.44 & $\mathrm{a}$ \\
\hline FERM domain containing 6 (FRMD6), transcript variant 2, mRNA & FRMD6 & ILMN_2330787 & 122786 & 0.42 & $b$ \\
\hline $\begin{array}{l}\text { Solute carrier family } 25 \text {, member } 29 \text { (SLC25A29), nuclear gene encoding } \\
\text { mitochondrial protein, mRNA }\end{array}$ & SLC25A29 & ILMN_2350801 & 123096 & 0.40 & $\mathrm{~b}$ \\
\hline $\begin{array}{l}\text { Solute carrier family } 25 \text { (mitochondrial carrier, brain), member } 14 \text { (SLC25A14), } \\
\text { nuclear gene encoding mitochondrial protein, transcript variant long, mRNA }\end{array}$ & SLC25A14 & ILMN_1743770 & 9016 & 0.39 & $\mathrm{a}$ \\
\hline $\begin{array}{l}\text { Acyl-Coenzyme A dehydrogenase, } \mathrm{C}-2 \text { to } \mathrm{C}-3 \text { short chain (ACADS), nuclear } \\
\text { gene encoding mitochondrial protein, mRNA }\end{array}$ & ACADS & ILMN_1795104 & 35 & -0.27 & $\mathrm{~b}$ \\
\hline DNA replication helicase 2 homolog (yeast) (DNA2), mRNA & DNA2 & ILMN_2282959 & 1763 & -0.57 & $\mathrm{~b}$ \\
\hline Protein kinase $\mathrm{C}$, alpha binding protein (PRKCABP), mRNA & PRKCABP & ILMN_1708159 & 9463 & -0.67 & $\mathrm{a}$ \\
\hline Apolipoprotein O-like (APOOL), mRNA & APOOL & ILMN_1777483 & 139322 & -0.68 & $\mathrm{a}$ \\
\hline Acyl-CoA synthetase medium-chain family member 5 (ACSM5), mRNA & ACSM5 & ILMN_1801698 & 54988 & -0.71 & $\mathrm{a}$ \\
\hline Estrogen receptor 2 (ER beta) (ESR2), transcript variant b, mRNA & ESR2 & ILMN_2390457 & 2100 & -0.74 & a \\
\hline PREDICTED: coiled-coil domain containing 56 (CCDC56), misc RNA & CCDC56 & ILMN_1789786 & 28958 & -0.86 & a \\
\hline Component of oligomeric golgi complex 8 (COG8), mRNA & COG8 & ILMN_1725246 & 84342 & -1.09 & $\mathrm{~b}$ \\
\hline \multicolumn{6}{|l|}{ Adhesion } \\
\hline Presenilin 1 (Alzheimer disease 3) (PSEN1), mRNA & PSEN1 & ILMN_1796669 & 5663 & 1.13 & $\mathrm{a}$ \\
\hline PREDICTED: p21 (CDKN1A)-activated kinase 2 (PAK2), mRNA & PAK2 & ILMN_1659878 & 5062 & 0.96 & a \\
\hline Reelin (RELN), transcript variant 1 , mRNA & RELN & ILMN_1753005 & 5649 & 0.89 & $\mathrm{~b}$ \\
\hline LIM and senescent cell antigen-like domains 1 (LIMS1), mRNA & LIMS1 & ILMN_2381037 & 3987 & 0.71 & $\mathrm{~b}$ \\
\hline Dystonin (DST), transcript variant 1e, mRNA & DST & ILMN_1675992 & 667 & 0.70 & a \\
\hline $\begin{array}{l}\text { Rap guanine nucleotide exchange factor (GEF) } 1 \text { (RAPGEF1), transcript variant } \\
2 \text {, mRNA }\end{array}$ & RAPGEF1 & ILMN_1678799 & 2889 & 0.50 & $\mathrm{a}$ \\
\hline Protocadherin 9 (PCDH9), transcript variant 2, mRNA & PCDH9 & ILMN_2379626 & 5101 & 0.46 & $\mathrm{~b}$ \\
\hline Phosphoglucomutase 5 (PGM5), mRNA & PGM5 & ILMN_2271149 & 5239 & 0.45 & $\mathrm{~b}$ \\
\hline Periostin, osteoblast specific factor (POSTN), mRNA & POSTN & ILMN_1790761 & 10631 & 0.44 & $\mathrm{~b}$ \\
\hline Claudin 15 (CLDN15), transcript variant 2, mRNA & CLDN15 & ILMN_1708267 & 24146 & 0.38 & a \\
\hline PREDICTED: p21 (CDKN1A)-activated kinase 2 (PAK2), mRNA & PAK2 & ILMN_1676385 & 5062 & 0.38 & a \\
\hline $\begin{array}{l}\text { Polycystic kidney and hepatic disease } 1 \text { (autosomal recessive) (PKHD1), } \\
\text { transcript variant } 1 \text {, mRNA }\end{array}$ & PKHD1 & ILMN_1720034 & 5314 & -0.30 & $\mathrm{~b}$ \\
\hline $\begin{array}{l}\text { Cadherin, EGF LAG seven-pass G-type receptor } 1 \text { (flamingo homolog, } \\
\text { Drosophila) (CELSR1), mRNA }\end{array}$ & CELSR1 & ILMN_1694482 & 9620 & -0.50 & $\mathrm{~b}$ \\
\hline $\begin{array}{l}\text { v-akt murine thymoma viral oncogene homolog } 3 \text { (protein kinase B, gamma) } \\
\text { (AKT3), transcript variant } 2 \text {, mRNA }\end{array}$ & AKT3 & ILMN_1733598 & 10000 & -0.59 & $\mathrm{~b}$ \\
\hline Junction plakoglobin (JUP), transcript variant 2 , mRNA & JUP & ILMN_2366864 & 3728 & -0.67 & a \\
\hline $\begin{array}{l}\text { Myeloid/lymphoid or mixed-lineage leukemia (trithorax homolog, Drosophila); } \\
\text { translocated to, } 4 \text { (MLLT4), transcript variant 3, mRNA }\end{array}$ & MLLT4 & ILMN_1746277 & 4301 & -0.77 & $\mathrm{~b}$ \\
\hline Cadherin-like $24(\mathrm{CDH} 24)$, transcript variant 1 , mRNA & $\mathrm{CDH} 24$ & ILMN_1693928 & 64403 & -0.83 & $\mathrm{a}$ \\
\hline $\begin{array}{l}\text { Rap guanine nucleotide exchange factor (GEF) } 1 \text { (RAPGEF1), transcript variant } \\
\text { 1, mRNA }\end{array}$ & RAPGEF1 & ILMN_1695282 & 2889 & -0.93 & $\mathrm{~b}$ \\
\hline
\end{tabular}


Table 5 continued

\begin{tabular}{|c|c|c|c|c|c|}
\hline Definition & Symbol & Probe_Id & $\begin{array}{l}\text { Entrez } \\
\text { Gene ID }\end{array}$ & $\begin{array}{l}\text { Mean } \\
2 \log \text { ratio }\end{array}$ & \\
\hline \multicolumn{6}{|l|}{ Inflammation } \\
\hline Presenilin 1 (Alzheimer disease 3) (PSEN1), mRNA & PSEN1 & ILMN_1796669 & 5663 & 1.13 & $\mathrm{a}$ \\
\hline Cathepsin C (CTSC), transcript variant 2 , mRNA & CTSC & ILMN_1689086 & 1075 & 0.78 & $\mathrm{~b}$ \\
\hline $\begin{array}{l}\text { Membrane-associated ring finger (C3HC4) } 8 \text { (MARCH8), transcript variant } 6 \text {, } \\
\text { mRNA }\end{array}$ & MARCH8 & ILMN_2341626 & 220972 & 0.78 & $\mathrm{a}$ \\
\hline Interleukin 7 receptor (IL7R), mRNA & IL7R & ILMN_2342579 & 3575 & 0.73 & $\mathrm{a}$ \\
\hline Interleukin 8 (IL8), mRNA & IL8 & ILMN_2184373 & 3576 & 0.66 & $\mathrm{a}$ \\
\hline $\begin{array}{l}\text { Tumor necrosis factor receptor superfamily, member 13C (TNFRSF13C), } \\
\text { mRNA }\end{array}$ & TNFRSF13C & ILMN_1731742 & 115650 & 0.63 & $\mathrm{a}$ \\
\hline Colony stimulating factor 1 (macrophage) (CSF1), transcript variant 4 , mRNA & CSF1 & ILMN_1805930 & 1435 & 0.52 & $\mathrm{~b}$ \\
\hline Epstein-Barr virus-induced 3 (EBI3), mRNA & EBI3 & ILMN_1802653 & 10148 & 0.51 & $\mathrm{a}$ \\
\hline $\begin{array}{l}\text { Apolipoprotein B mRNA editing enzyme, catalytic polypeptide-like } 3 \mathrm{~F} \\
\text { (APOBEC3F), transcript variant } 1 \text {, mRNA }\end{array}$ & APOBEC3F & ILMN_1710726 & 200316 & 0.49 & $\mathrm{~b}$ \\
\hline Neutrophil cytosolic factor 1 (NCF1), mRNA & NCF1 & ILMN_1697309 & 653361 & 0.38 & $\mathrm{a}$ \\
\hline Cathepsin C (CTSC), transcript variant 1 , mRNA & CTSC & ILMN_2242463 & 1075 & 0.34 & $\mathrm{~b}$ \\
\hline $\mathrm{B}$ and $\mathrm{T}$ lymphocyte associated (BTLA), transcript variant 1, mRNA & BTLA & ILMN_1778536 & 151888 & -0.19 & $\mathrm{a}$ \\
\hline Chemokine (C-X-C motif) receptor 5 (CXCR5), transcript variant 2, mRNA & CXCR5 & ILMN_2337931 & 643 & -0.42 & $\mathrm{a}$ \\
\hline Interleukin 1 receptor, type II (IL1R2), transcript variant 2, mRNA & IL1R2 & ILMN_1772131 & 7850 & -0.60 & $\mathrm{~b}$ \\
\hline Lymphocyte transmembrane adaptor 1 (LAX1), mRNA & LAX1 & ILMN_1769782 & 54900 & -0.61 & $\mathrm{a}$ \\
\hline Serum amyloid A1 (SAA1), transcript variant 1 , mRNA & SAA1 & ILMN_1701017 & 6288 & -0.68 & $\mathrm{~b}$ \\
\hline Virus-induced signaling adapter (VISA), mRNA & VISA & ILMN_2131493 & 57506 & -0.69 & $\mathrm{a}$ \\
\hline $\begin{array}{l}\text { Tumor necrosis factor (ligand) superfamily, member } 12 \text { (TNFSF12), transcript } \\
\text { variant } 2 \text {, mRNA }\end{array}$ & TNFSF12 & ILMN_1680003 & 8742 & -0.75 & $\mathrm{a}$ \\
\hline Serum amyloid A1 (SAA1), transcript variant 1 , mRNA & SAA1 & ILMN_1808732 & 6288 & -1.29 & $\mathrm{a}$ \\
\hline
\end{tabular}

a: $p$ for interaction between intervention and group $<0.05$; b: $p$ for intervention $<0.05$. Genes showed consistent expression change in obese subjects ( $>25 \%$ up or $>25 \%$ down in at least 6 subjects)

health effects of increased vegetable intake in both lean and obese subjects and elucidate some of the underlying mechanisms. The responsive markers included classical markers ASAT and ALP, plasma amino acids and oxylipins quantified by metabolic profiling as well as adipose tissue gene expression. The latter results suggest that both vegetable intake and weight reduction is differently regulated in lean and obese subjects. Data integration through network analysis illustrated a central role for NFkB in (adipose tissue) modulation of inflammation by increased vegetable intake, in lean as well as obese subjects. Plasma inflammatory cytokines did not change in response to increased vegetable intake, with the exception of TNF- $\alpha$ that showed lower concentrations in lean subjects. In obese subjects, high vegetable intake also resulted in adipose tissue gene expression changes related to energy metabolism and cell adhesion.

Subjects consumed both fresh and canned vegetables; the types of vegetables offered were the most popular types: (fresh) tomatoes, cauliflower, beet, onions; (canned) peas, broad beans, French beans, carrots, corn. Body weight remained stable through both high and low vegetable intakes. The finding that the highest treatment dose of $200 \mathrm{~g}$ of vegetables daily affects physiological processes in a direction that is associated with health benefits supports the advice on the Dutch Health Council to consume $200 \mathrm{~g}$ of vegetables daily (Health Council of the Netherlands 2006). Higher dosages of vegetables could scientifically be even more interesting; however, this will be considerably challenging for public health implementation and probably not yet realistic. In public surveys, it was found that on average about $2 \%$ of the Dutch population consume $150 \mathrm{~g}$ of vegetables daily, and therefore, even $200 \mathrm{~g}$ daily may already provide a challenging target.

In the present study investigating health effects of vegetables, an energy restriction intervention was included to determine whether similar processes are present and similar effects on health were found. Although the subjects did not lose a lot of weight, still beneficial health effects were seen at the level of classical markers including weight loss, decreases in total cholesterol, LDL cholesterol, ratio of cholesterol/HDL and HbA1c. It was already known that about $5 \%$ weight loss is beneficial for health (Wing et al. 1992; Tuomilehto et al. 2001; Calder et al. 2011). We 


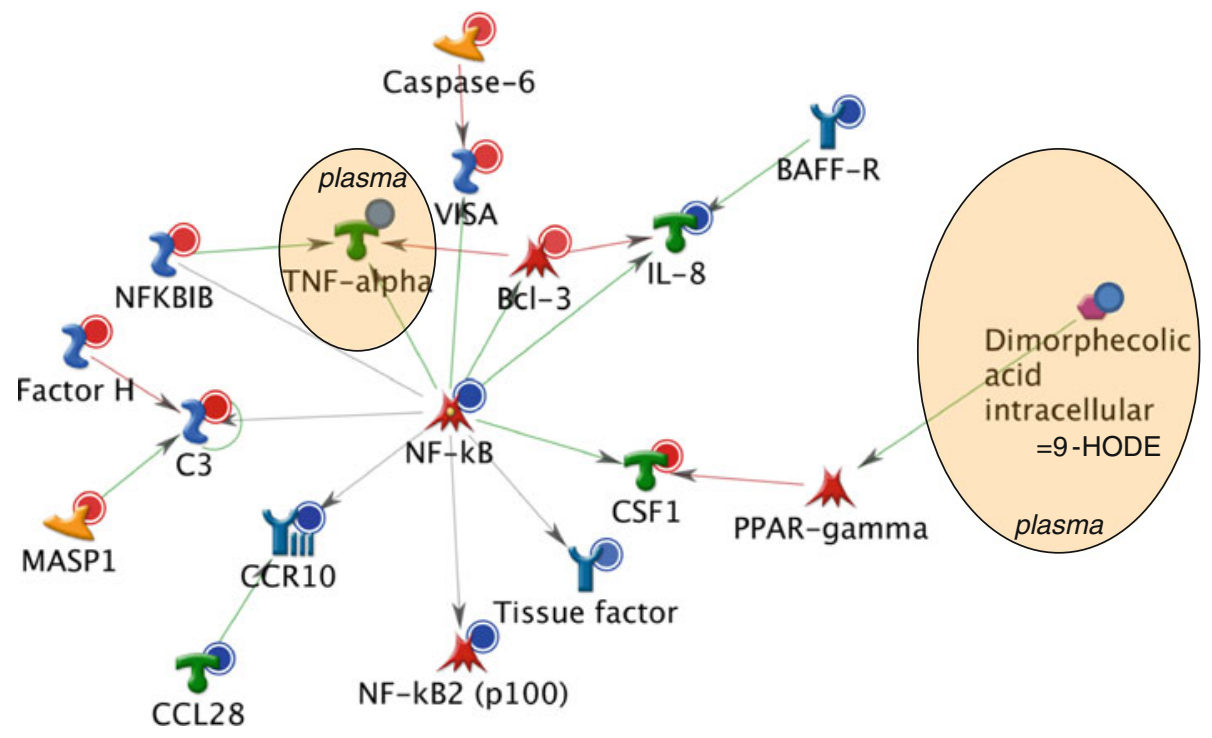

Fig. 2 Network showing biological links between genes involved in inflammation and plasma markers that respond to high vegetable intake in lean subjects. Red circle indicates up-regulation in response to high vegetable intake, blue circle indicates down-regulation in response to high vegetable intake. $B A F F-R$ tumor necrosis factor receptor superfamily, member $13 \mathrm{C} ; B c l-3 \mathrm{~B}$ cell CLL/lymphoma 3; C3 complement component 3; CCL28 chemokine (C-C motif) ligand
28; CCR10 chemokine (C-C motif) receptor 10; CSF1 colony stimulating factor 1 (macrophage); Factor $H$ complement factor $\mathrm{H}$; IL-8: interleukin 8; MASP1: mannan-binding lectin serine peptidase 1 (C4/C2 activating component of Ra-reactive factor); $N F-k B$ : nuclear factor-kappa-B; $N F K B I B$ I-kappa-B-beta; $P P A R-\gamma$ peroxisome proliferator-activated receptor gamma; $T N F-\alpha$ tumor necrosis factor alpha; VISA mitochondrial antiviral signaling protein

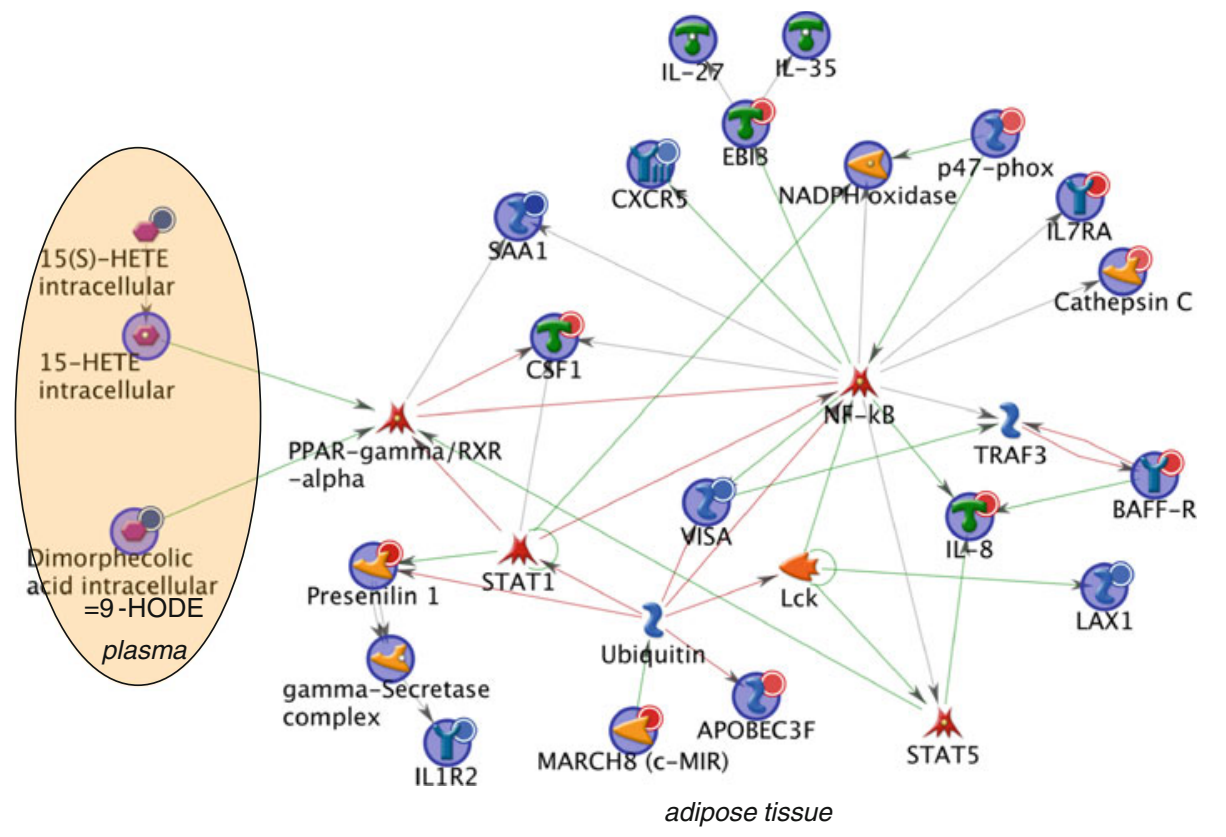

Fig. 3 Network showing biological links between genes involved in inflammation and plasma markers that respond to high vegetable intake in obese subjects. Red circle indicates up-regulation in response to high vegetable intake, blue circle indicates downregulation in response to high vegetable intake. $A P O B E C 3 F$ : apolipoprotein B mRNA editing enzyme, catalytic polypeptide-like $3 \mathrm{~F}$; $B A F F-R$ tumor necrosis factor receptor superfamily, member 13C; CSF1 colony stimulating factor 1 (macrophage); EBIB EpsteinBarr virus-induced 3, IL-27 subunit beta; $C X C R 5$ chemokine (C-X-C motif) receptor 5; 15(S)-HETE 15-HETE; IL1R2: interleukin-1 receptor type 2; IL-8 interleukin-8; $I L-27$ interleukin-27; $I L-35$ interleukin-35; LAX1 lymphocyte transmembrane adaptor 1; Lck tyrosine-protein kinase Lck; MARCH8 (c-MIR) membrane-associated ring finger (C3HC4) 8; NF- $k B$ nuclear factor-kappa-B; p47-phox neutrophil cytosolic factor $1 ; P P A R-\gamma$ peroxisome proliferatoractivated receptor gamma; $R X R-\alpha$ retinoid $\mathrm{X}$ receptor, alpha; $S A A 1$ serum amyloid A1; STAT1 signal transducer and activator of transcription 1; STAT5 signal transducer and activator of transcription 5; TRAF3 TNF receptor-associated factor 3; VISA mitochondrial antiviral signaling protein 


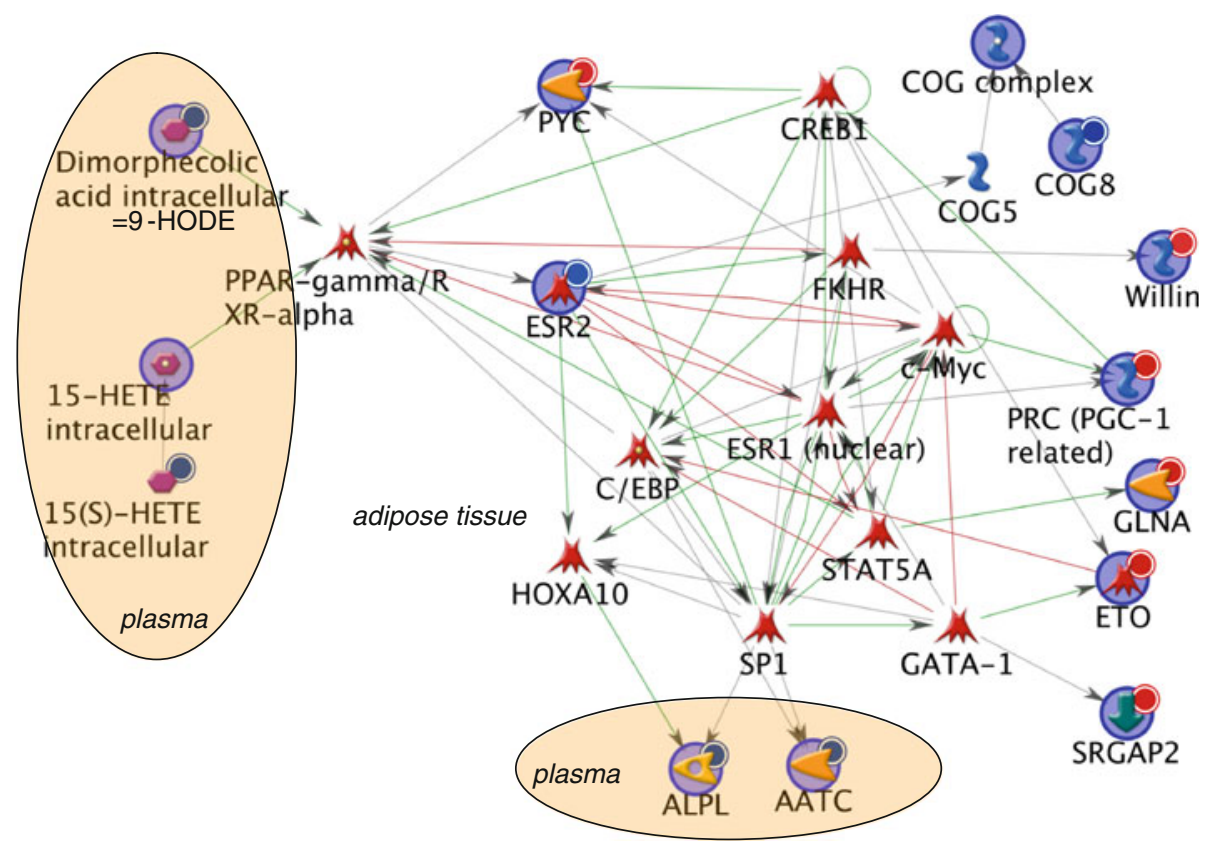

Fig. 4 Network showing biological links between genes involved in energy metabolism and plasma markers that respond to high vegetable intake in obese subjects. Red circle indicates up-regulation in response to high vegetable intake, blue circle indicates downregulation in response to high vegetable intake. AATC glutamicoxaloacetic transaminase 1, soluble (aspartate aminotransferase 1); $A L P L$ alkaline phosphatase, liver/bone/kidney; C/EBP CCAAT/ enhancer binding protein (C/EBP); COG complex component of oligomeric golgi complex; COG5 component of oligomeric golgi complex 5; COG8 component of oligomeric golgi complex 8; CREB1 cAMP responsive element binding protein 1; $c-M y c$ v-myc myelocytomatosis viral oncogene homolog (avian); ESRl (nuclear)

report in the present study that $2 \%$ body weight loss significantly affects established biomarkers of (cardiovascular) health.

After 8 weeks of prescribed vegetable consumption, subjects were instructed to eat in total less energy. The energy-restricted diet intervention was deliberately designed at the end of the study for all subjects, because we expected clear physiological impact due to energy restriction. This could not be implemented during the low/high vegetable intake intervention because it would have influenced the differences in vegetable intake. As a period $a d$ random in the crossover trial, it would have affected the vegetable interventions too much, and therefore, only the vegetable interventions were designed as a crossover with an energy-restricted period afterward for all subjects.

In contrast to the energy restriction intervention, plasma markers did not show clear health benefits due to increased vegetable consumption. Two liver enzymes, ALP and ASAT, showed decreased concentrations after 4 weeks of $200 \mathrm{~g}$ of vegetable consumption. In lean subjects, the TNF$\alpha$ level decreased with high vegetable consumption. The sensitive metabolic profiling analyses showed additional estrogen receptor 1; ESR2 estrogen receptor 2 (ER beta); ETO runtrelated transcription factor 1 ; translocated to, 1 (cyclin D-related); FKHR forkhead box 01; GATA-1 GATA binding protein 1 (globin transcription factor 1); GLNA glutamate-ammonia ligase; 15(S)HETE 15S-hydroxyeicosatetraenoic acid; 15-HETE 15-hydroxyeicosatetraenoic acid; HOXA10 homeobox A10; PPAR- $\gamma$ peroxisome proliferator-activated receptor gamma; $R X R-\alpha$ retinoid $\mathrm{X}$ receptor, alpha; $P R C$ ( $P G C-1$ related) peroxisome proliferator-activated receptor gamma, coactivator-related 1; $P Y C$ pyruvate carboxylase; $S P 1 \mathrm{Sp} 1$ transcription factor; SRGAP2 SLIT-ROBO Rho GTPase activating protein 2; STAT5A signal transducer and activator of transcription 5A; Willin FERM domain containing 6

health effects. High vegetable intake resulted in significantly increased plasma levels of four amino acids (derivatives): asparagine, leucine, methionine sulfoxide and threonine. The amino acids may directly originate from the consumed vegetables and thus leading to increased plasma levels. So far, only O'Sullivan reported on dietary intake patterns among which vegetable consumption and their reflection in plasma and urinary metabolic profiles (O'Sullivan et al. 2011). Unfortunately, nothing was reported on vegetable intake and their plasma reflection on amino acids, so therefore, this finding could not be confirmed. Methionine sulfoxide is a well-known biomarker for oxidative stress, which occurs by oxidation of methionine residues to methionine sulfoxide (Mashima et al. 2003). It can be produced in vivo, but it is also known that plants produce this metabolite in response to stress (Emes 2009), since the relative response of this plasma metabolite to an a maximal exercise challenge is significantly lower in the subjects on high vegetables compared to low vegetables in this study, which was interpreted that high vegetables protected subjects from the acute in vivo damage by oxidative stress (results not shown). Furthermore, it is known 
that processing of foods can lead to modifications of proteins by oxidation, such as methionine sulfoxide (Rutherfurd and Moughan 2008). Taken together, we interpreted the significant increase in plasma methionine sulfoxide concentrations likely to be due to the higher intake of processed vegetables. Levels of lipid-derived metabolites 9-HODE, 15-HETE and prostaglandin D3 decreased in response to the $200 \mathrm{~g}$ vegetable intake compared to $50 \mathrm{-g}$ vegetable intake. 9-HODE and 15-HETE are both reduced products synthesized from, respectively, linoleic acid and arachidonic acid in the 12- and 15-lipoxygenase (LOX) pathways. These pathways are associated with LDL oxidation and subsequently with atherosclerotic lesions (Imaizumi et al. 2010). 9(S)-HODE and 13(S)-HODE are known as lipid peroxidation markers that can be used for the estimation of oxidative stress in human (Spiteller and Spiteller 1997). The oxylipin 13(S)-HODE showed a trend for treatment effect ( $p$ value 0.0543 ) with similar direction as 9-HODE and 15-HETE. Therefore, decreased concentrations of products from the 12- and 15-LOX pathways suggest decreased oxidative stress in subjects in response to high vegetable intake. This illustrates that subtle, beneficial processes take place and can be shown with this technology when classical markers do not show any effect.

In addition to the plasma metabolic profiling, we studied effects of the nutritional interventions in adipose tissue by whole-genome expression profiling. Previously, we and others have shown that nutritional intervention can result in adipose tissue gene expression changes (van Erk et al. 2008; Radonjic et al. 2009), including effects on inflammatory processes. Furthermore, it is expected that energy restriction and body weight loss result in changes in adipose tissue, specifically in obese subjects (Márquez-Quiñones et al. 2010; Bouchard et al. 2010). In obese subjects, weight loss due to the energy restriction was associated with changes in processes related to energy metabolism: oxidative phosphorylation, mitochondrial function, generation of precursor metabolites and energy. Also, process of adhesion and $\mathrm{T}$ cell activation (inflammation) were changed in concordance with weight loss. These processes are also reported in studies investigating adipose tissue response to very-low-calorie diets in obese subjects (Clément et al. 2004; Franck et al. 2011).

High vegetable intake resulted in subtle gene expression changes in adipose tissue. We selected differentially expressed genes based on statistics combined with a fold change threshold ( $>25 \%$ up or $>25 \%$ down in at least 6 subjects). This approach takes into account inter-individual variation in response while still identifying group effects of a certain effect size. By submitting the selected sets of differentially expressed genes to enrichment analysis, we could identify the biological processes affected by increased vegetable intake. In lean subjects, increased vegetable consumption affected adipose tissue inflammation, as measured by gene expression. Through network analysis based on biological knowledge, we could visualize direct links between 15 adipose tissue genes with a role in inflammation. These genes were directly linked to TNFalpha, for which plasma levels were decreased by increased vegetable intake in lean subjects. Within the group of obese subjects, increased vegetable intake resulted in a smaller set of differentially expressed genes that was not enriched for biological processes. This may be due to a larger variation in response to the obese group of subjects. We have seen such a larger response variation (factor two different) in a previous study as well (van Erk et al. 2008).

Weight loss is a well-accepted health benefit for obese subjects (Wing et al. 1992; Tuomilehto et al. 2001; Calder et al. 2011). By correlating adipose tissue gene expression changes to body weight change after caloric restriction, we identified pathways or processes that are associated with this health benefit. These processes were only identified in the obese subjects. This makes sense as these subjects, being overweight, would benefit most from weight loss. In obese subjects, high vegetable intake resulted in differential expression of small sets of genes in all three processes: adhesion, energy metabolism and inflammation. In order to visualize biological links between these adipose tissue genes, plasma proteins and plasma metabolites, biological network analysis was performed The plasma metabolites related to amino acids were included in the network but did not appear to be involved in the inflammation processes. The network of inflammation genes revealed a central role of NFkB as regulator of inflammatory gene expression changes in adipose tissue due to high vegetable intake. Therefore, it could be hypothesized that in both lean and obese subjects, increased vegetable intake affects inflammatory processes in adipose tissue through NFkB. Also, the networks show a link of these adipose tissue inflammatory responses with decreases in plasma oxylipins 9-HODE and 15-HETE, through PPAR $\gamma / \mathrm{RXR} \alpha$. These oxylipins are known to play a role in oxidative stress.

The network of energy metabolism genes also shows a connection to plasma oxylipins through PPAR $\gamma / \mathrm{RXR} \alpha$. This network includes a range of transcription factors that could be involved rather than one central regulator for inflammation. Interestingly, this network includes ASAT (AATC) and ALP (ALPL), indicating a potential biological link between these markers and adipose tissue gene expression changes related to energy metabolism.

The network of adhesion genes did only reveal a link to plasma ALP and not to other plasma markers or central regulators.

Network analysis has the advantage of combined analysis of markers from different levels (gene, protein, metabolite) and of focus on biological connections between 
markers that show a significant response. The networks provide hypotheses of possible effects and mechanisms of health-promoting effects of high vegetable intake that can be investigated in more detail.

\section{Conclusion}

By inclusion of sensitive omics technologies and comparing the changes induced by high vegetable intake with changes induced by energy restriction and associated with weight loss, it has been shown that part of vegetables' health benefits are mediated by changes in energy metabolism, inflammatory processes and oxidative stress.

Acknowledgments We would like to thank the subjects participating in the study. Henriëtte Fick, Desiree Rouwendal, José Jacobs, Inge van den Assum, Angelique Speulman and Christel Hoeflaken, are thanked for conducting the study. We thank Karin Toet for sample preparation for RNA isolation and transcriptome analysis and Carina de Jong-Rubingh for statistical support. The firm Heinz BV kindly enabled Metabolomics analysis in the study. This study was financially supported by the Dutch government through grant "Healthy nutrition" (Grant number 04003).

Conflict of interest None disclosed.

Open Access This article is distributed under the terms of the Creative Commons Attribution License which permits any use, distribution, and reproduction in any medium, provided the original author(s) and the source are credited.

\section{References}

Abdullah A, Peeters A, de Courten M, Stoelwinder J (2010) The magnitude of association between overweight and obesity and the risk of diabetes: a meta-analysis of prospective cohort studies. Diabetes Res Clin Pract 89:309-319

Bakker GC, van Erk MJ, Pellis L, Wopereis S, Rubingh CM, Cnubben NH, Kooistra T, van Ommen B, Hendriks HF (2010) An anti-inflammatory dietary mix modulates inflammation and oxidative and metabolic stress in overweight men: a nutrigenomics approach. Am J Clin Nutr 91:1044-1059

Balvers MHJ, Verhoeckx KCM, Meijerink J, Bijlsma S, Rubingh CM, Wortelboer HM, Witkamp RF (2012) Fish oil and inflammatory status alter the n-3 to n- 6 balance of the endocannabinoid and oxylipin metabolomes in mouse plasma and tissues. Metabolomics. doi:10.1007/s11306-012-0421-9

Bazzano LA, Li TY, Joshipura KJ, Hu FB (2008) Intake of fruit, vegetables, and fruit juices and risk of diabetes in women. Diab Care 31:1311-1317

Boden G (2008) Obesity and free fatty acids. Endocrinol Metab Clin North Am 37:635-ix

Bouchard L, Rabasa-Lhoret R, Faraj M, Lavoie ME, Mill J, Pérusse L, Vohl MC (2010) Differential epigenomic and transcriptomic responses in subcutaneous adipose tissue between low and high responders to caloric restriction. Am J Clin Nutr 91:309-320

Calder PC, Ahluwalia N, Brouns F, Buetler T, Clément K, Cunningham K, Katherine Esposito K, Jönsson LS, Kolb H, Lansink M,
Marcos A, Margioris A, Matusheski N, Nordmann H, O’Brien J, Pugliese G, Rizkalla S, Schalkwijk C, Tuomilehto J, Wärnberg J, Watzl B, Winklhofer-Roob BM (2011) Dietary factors and lowgrade inflammation in relation to overweight and obesity. Br J Nutr 106:S1-S78. doi:10.1017/S0007114511005460

Chen D, Bruno J, Easlon E, Lin SJ, Cheng HL, Alt FW, Guarente L (2008) Tissue-specific regulation of SIRT1 by calorie restriction. Genes Dev 22(13):1753-1757

Clément K, Viguerie N, Poitou C, Curette C, Palloux V, Curat CA, Sigard A et al (2004) Weight loss regulates inflammation-related genes in white adipose tissue of obese subjects. FASEB J 18:1657-1669

Emerging Risk Factors Collaboration (2011) Separate and combined associations of body-mass index and abdominal adiposity with cardiovascular disease: collaborative analysis of 58 prospective studies. Lancet 377:1085-1095

Emes MJ (2009) Oxidation of methionine residues: the missing link between stress and signalling responses in plants. Biochem $\mathrm{J}$ 422:e1-e2

Fisher-Wellman K, Bloomer RJ (2009). Acute exercise and oxidative stress: a 30 year history. Review. Dynamic Med 8: I. doi: 10.1186/1476-5918-8-1

Franck N, Gummesson A, Jernås M, Glad C, Svensson PA, Guillot G, Rudemo M, Nyström FH, Carlsson LM, Olsson B (2011) Identification of adipocyte genes regulated by caloric intake. J Clin Endocrinol Metab 96:E413-E418

Gonzalez CA, Lujan-Barroso L, de Mesquita HB, Jenab M, Duell EJ, Agudo A et al (2012). Fruit and vegetable intake and the risk of gastric adenocarcinoma: a reanalysis of the European prospective investigation into cancer and nutrition (EPIC-EURGAST) study after a longer follow-up. Int J Cancer. doi:10.002/ijc.27565

Hayes J, Kelleher M, Eggleston I (2008) The cancer chemopreventive actions of phytochemicals derived from glucosinolates. Eur $\mathbf{J}$ Nutr 47:73-88

Health Council of the Netherlands (2006) Guidelines for a healthy diet 2006. The Hague: Health Council of the Netherlands (publication no. 2006/21)

Hu FB (2003) Plant-based foods and prevention of cardiovascular disease: An overview. Am J Clin Nutr 78(3S):544S-551S

Huang DW, Sherman BT, Lempicki RA (2009) Systematic and integrative analysis of large gene lists using DAVID Bioinformatics Resources. Nat Protoc 4(1):44-57

Imaizumi S, Grijalva V, Navab M, van Lenten BJ, Wagner AC, Anantharamaiah GM, Fogelman AM, Reddy ST (2010) L-4F differentially alters plasma levels of oxidized fatty acids resulting in more anti-inflammatory HDL in mice. Drug Metab Lett 4:139-148

Kolaczynski JW, Morales LM, Moore JH, Consindine RV, Pietrzkowski Z, Noto PF, Colberg J, Caro JF (1994) A new technique for biopsy of human abdominal fat under local anaesthesia with lidocaine. Int J Obes 18:161-166

Krebs-Smith SM, Kantor LS (2001) Choose a variety of fruits and vegetables daily: understanding the complexities. J Nutr 131(2S1):487S-501S

La Vecchia C, Giordano SH, Hortobagyi GN, Chabner B (2011) Overweight, obesity, diabetes, and risk of breast cancer: interlocking pieces of the puzzle. Oncologist 16:726-729

Lock K, Pomerleau J, Causer L, Altmann DR, McKee M (2005) The global burden of disease attributable to low consumption of fruit and vegetables: implications for the global strategy on diet. Bull World Health Organ 83:100-108

Márquez-Quiñones A, Mutch DM, Debard C, Wang P, Combes M, Roussel B et al; DIOGenes Project (2010) Adipose tissue transcriptome reflects variations between subjects with continued weight loss and subjects regaining weight 6 mo after caloric restriction independent of energy intake. Am $\mathrm{J}$ Clin Nutr 92:975-984 
Martin LJ, Lee S-Y, Couch SC, Morrison J, Woo JG (2011) Shared genetic contributions of fruit and vegetable consumption with BMI in families $20 \mathrm{y}$ after sharing a household. Am J Clin Nutr 94:1138-1143

Martinez-González MA, de la Fuente-Arrilaga C, López-del-Burgo C, Vázquez-Ruiz Z, Benito S, Ruiz-Canela M (2011) Low consumption of fruit and vegetables and risk of chronic disease: a review of the epidemiological evidence and temporal trends among Spanish graduates. Public Health Nutr 14:2309-2315

Mashima R, Nakanishi-Ueda T, Yamamoto Y (2003) Simultaneous determination of methionine sulfoxide and methionine in blood plasma using gas chromatography-mass spectrometry. Anal Biochem 313:28-33

Mosby TT, Cosgrove M, Sarkardei S, Platt KL, Kaina B (2012) Nutrition in adult and childhood cancer: role of carcinogens and anti-carcinogens. Anticancer Res 32:4171-4192

Myint PK, Smith RD, Luben RN, Surtees PG, Wainwright NWJ, Wareham NJ, Khaw K-T (2011) Lifestyle behaviours and quality-adjusted life years in middle and older age. Age Ageing 40:589-595

O’Sullivan A, Gibney MJ, Brennan L (2011) Dietary intake patterns are reflected in metabolomic profiles: potential role in dietary assessment studies. Am J Clin Nutr 93:314-321

Radonjic M, van Erk MJ, Pasman WJ, Wortelboer HM, Hendriks HF, van Ommen B (2009) Effect of body fat distribution on the transcription response to dietary fat interventions. Genes Nutr 4:143-149

Ros MM, Bas Buono-de-Mesquita H, Kampman E, Büchner FL, Aben KK, Egevad L et al (2012). Fruit and vegetable consumption and risk of aggressive and non-aggressive urothelial cell carcinomas in the European Prospective Investigation into Cancer and Nutrition. Eur J Cancer 48:3267-3277

Rosenling T, Slim CL, Christin C, Coulier L, Shi S, Stoop MP, Bosman J, Suits F, Horvatovich PL, Stockhofe-Zurwieden N, Vreeken R, Hankemeier T, van Gool AJ, Luider TM, Bischoff R (2009) The effect of preanalytical factors on stability of the proteome and selected metabolites in cerebrospinal fluid (CSF). J Proteome Res 8:5511-5522
Rutherfurd SM, Moughan PJ (2008) Determination of sulfur amino acids in foods as related to bioavailability. J AOAC Int 91(4):907-913

Spiteller P, Spiteller G (1997) 9-Hydroxy-10,12-octadecadienoic acid (9-HODE) and 13-hydroxy-9,11-octadecadienoic acid (13HODE): excellent markers for lipid peroxidation. Chem Phys Lipids 89:131-139

Tomás-Barberán FA, Robins RJ (1997) Phytochemistry of fruit and vegetables. In: Proceedings of Phytochemical Society of Europe. Oxford Science Publications, Oxford, UK

Tuomilehto J, Lindström J, Eriksson JG, Valle TT, Hämäläinen H, Ilanne-Parikka P et al (2001) Prevention of type 2 diabetes Mellitus by changes in lifestyle among subjects with impaired glucose tolerance. New Eng J Med 344:1343-1350

Van Erk MJ, Pasman WJ, Wortelboer HM, van Ommen B, Hendriks HF (2008) Short-term fatty acid intervention elicits differential gene expression responses in adipose tissue from lean and overweight men. Genes Nutr 3:127-137

Villegas R, Shu XO, Gao Y-T, Yang G, Elasy T, Li H, Zheng W (2008) Vegetable but not Fruit consumption reduces the risk of Type 2 diabetes in Chinese women. J Nutr 138:574-580

WCRF, Fund WCR \& Cancer AIf (2007) Research, food, nutrition, physical activity, and the prevention of cancer: a global perspective. American Institute of Cancer Research, Washington, DC

Wing RR, Jeffery RW, Burton LR, Thorson C, Kuller LH, Folsom AR (1992) Change in waist-hip ratio with weight loss and its association with change in cardiovascular risk factors. Am J Clin Nutr 55:1086-1092

Wolin KY, Carson K, Colditz GA (2010) Obesity and Cancer. Oncologist 15:556-565

Yao LH, Jiang YM, Shi J, Tomás-Barberán FA, Datta N, Singanusong R, Chen SS (2004) Flavonoids in food and their health benefits. Plant Foods Hum Nutr 59:113-122

Yusuf S, Hawken S, Ounpuu S, Bausista L, Franzosi MG, Commerford P et al (2005) Obesity and the risk of myocardial infarction in 27000 participants from 52 countries: a case-control study. Lancet 366:1640-1649 